How to cite: Suciu, G., Bălănescu, M., Birdici, A., Orza, O., Pasat, A., Dobrea, M.A., Bălăceanu, C.M. (2020) Assessment of Particulate Matter Concentration in Underground Transport Work Environment. 2020 "Air and Water - Components of the Environment" Conference Proceedings, Cluj-Napoca, Romania, p. 37-46, DOI: 10.24193/AWC2020_04.

\title{
ASSESSMENT OF PARTICULATE MATTER CONCENTRATION IN UNDERGROUND TRANSPORT WORK ENVIRONMENT
}

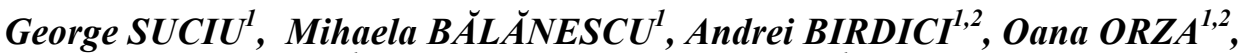 \\ Adrian PASAT ${ }^{1}$, Marius Alexandru DOBREA ${ }^{1}$, Cristina Mihaela \\ B $\breve{A L} \breve{A C E A N U^{I}}$
}

DOI: 10.24193/AWC2020_04

\begin{abstract}
Air quality sensors networks are an interesting topic for research and development as they can provide valuable information about pollution sources and levels. Metro systems are a vital component of large cities by enabling affordable and fast transportation. The air input for the subways is coming from street level admission points that are affected by traffic pollution so, a system for monitoring and assessment of the air in the underground infrastructure is also crucial. This paper describes an IoT network that was designed to monitor the environment in hazardous work areas and to estimate the pollutants concentrations values in the underground transport infrastructure. The goal of the paper is defining a system capable of collecting as much information as possible about the air quality level in underground infrastructures. For the data acquisition part, a total of five equipment was installed in the pilot location both for monitoring but also for communication purpose between the devices. Two models for prediction of the PM10 and PM2.5 concentrations were elaborated, tested and validated on a data set represented by 200 values of hourly concentrations for each of the $\mathrm{PM}_{10}$ and $\mathrm{PM}_{2.5}$ pollutants. The results show that the main pollution source is represented by the urban road traffic pollution and the model predicts very well the concentration inside the underground environment.
\end{abstract}

Keywords: Air Quality, IoT, PMs, models

\section{INTRODUCTION}

The data from World Health Organisation (WHO) reveals that 9 out of 10 people inhale polluted air (WHO, 2019). Particulate Matter (PM) is the pollutant with the highest exceeding over WHO's safe limits. Various researches and studies have proved a straight relationship between exposure to high PM concentrations and harmful effects

\footnotetext{
${ }^{1}$ BEIA Consult International, St. Peroni 16, Bucharest, 041386, Romania george@beia.ro mihaela.balanescu@beia.ro andrei.birdici@beia.ro oana.orza@beia.ro adrian.pasat@beia.ro marius.dobrea@beia.ro,cristina.balaceanu@beia.ro

${ }^{2}$ University Politehnica of Bucharest, St. Splaiul Independentei 313, Bucharest, 060042, andrei.birdici@stud.energ.upb.ro, oana.orza@stud.etti.upb.ro
} 
on human health. The smaller the particles are in diameter the more harmful they are, ultrafine ones being able to penetrate organs and tissues (WHO, 2019). Almost 4 million people die every year from diseases connected to indoor air pollution.

In general terms, human health risk depends on the three factors (i) quantity of a chemical that exist in an environmental medium (e.g., soil, water, air), (ii) exposure time - period when a person is in contact with the contaminated environmental medium, and (iii) the toxicity of the chemical.

This paper is based on the WINS@HI project that has the main objective, the design of a system that is capable of capturing information about the hazardous work environments, the network infrastructure and the health of the workers. In such hazardous environments, there is a high level of risk that could be divided in two ways. The first category is the acute risk that can have immediate effects or within a few hours to a day. The second one is represented by the chronic risk with noticeable effects becoming visible after a longer period of time.WINS@HI project addresses both types of risks and provides data driven decision making systems for mitigation of human health risk and improvements of working environments in Hazardous Industrial Environments.

Occupational risks (Fig. 1) are the source for a meaningful percentage of health diseases like back pain and loss of hearing (26\%), chronic obstructive pulmonary disease (12\%), unintentional poisoning (14\%). Also, $25 \%$ of the heart strokes are caused by the indoor air pollution.

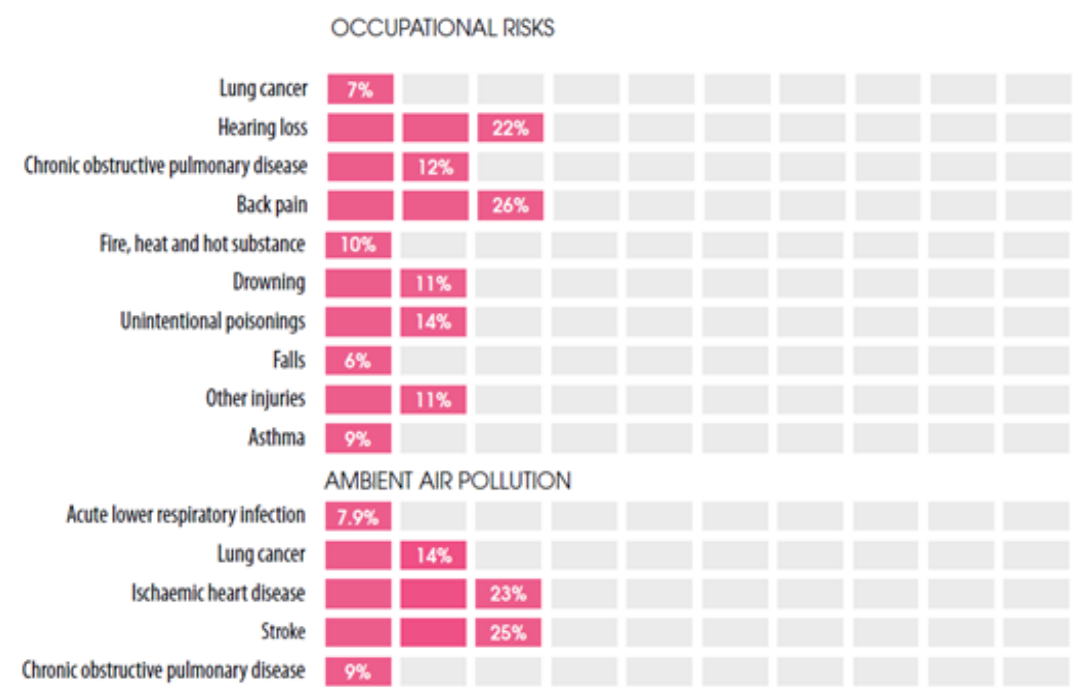

\section{Fig. 1. Incidence of various disease/injuries considering occupational risks and ambient air pollution factor (Prüss-Üstün et al, 2016)}

Hazardous environments are exposed to a series of problems from the operational and security point of view, at the same time that they present some limitations in terms of performance or use of certain technologies and protocols. In this way, some of the main problems within these Hazardous environments are: 
- Inefficiencies of the productive processes due to errors or accidents;

- Exposure to risks derived from the working environment;

- Vulnerabilities and Attacks on its Network infrastructure.

\section{RELATED WORK}

Worldwide, several studies were published with the focus on assessment of air quality in the underground transport network. In Beijing's metro stations, authors of article (Pan et al., 2018) presented that PM concentrations variation are related with the arrival of the train in the station. The train produces a piston wind effect and it can be a cause of these PMs concentration. As long as the door is opened, inside the train the measurements showed a considerable oscillation of $\mathrm{PM}_{2.5}$ from $220 \mu \mathrm{g} / \mathrm{m}^{3}$ to $370 \mu \mathrm{g} / \mathrm{m}^{3} .8$ distinct rooms were monitored around the working places of the metro from which only 3 of the rooms had installed a system for ventilation and one of the others was closed. The day when the measurements were performed, was a polluted one and the authors concluded their work with a concentration of PM pollution, higher than the one outside. The rooms with the highest contaminate air were the ones with poor systems for ventilation and the room with the lowest PM concentration is the closed one. The average ratio of the $\mathrm{PM}_{2.5}$ and $\mathrm{PM}_{10}$ outside the subway was $79.6 \%$ and inside the metro was $68.7 \%$.

The authors of the article (Carteni et al., 2014) have inspected the progression of $\mathrm{PM}_{10}$ pollution levels in a new section of a subway line, in Italy. Then they compared the results with the values measured in a metro line, section which was older. The comparison was made from a statistical point of view in both cases, and the pollutants were removed from the old to the new section being in the presence of the piston effect.

In the previous studies (Carteni et al., 2018), it was demonstrated that the concentrations of PMs that were measured in metro systems are much higher than the values which were measured at the street level. This happens because of the mechanical processes of the trains. The authors concluded their experiments with an analysis of the air quality improvement in the case of applying high quality materials and also solutions for the metro system.

A study (Barmparesos et al., 2016) was made in four different subways stations in Greece, Athens and it had as result the comparison of several locations in terms of air quality, depending on the type of ventilation installed such as air conditioning or natural ventilation. The authors made measurements continuously having portable devices. The results were influenced by the deepness and crowdedness of the metro station.

In the study (Perrinoet al., 2015), the authors measured the air pollution due to PM concentration existing in one of the most important metro stations in Rome. They managed to study and compare various outdoor and indoor environments. Besides that, it can be seen that in this paper an important role is given by the air conditioning in the measurement of the air quality for an indoor environment. The results are compared with both optical particle counter and gravimetric procedure methods. 
The study (Aarnio et al., 2005) was led to identify street traffic as a source of the pollution that have particles with the size below $500 \mathrm{~nm}$ in the metro station. The comparison of the distributions of PMs was an important factor in fulfilling the correlation.

\section{METHODS}

The main pollutants inside the underground areas are gaseous pollutants and PMs. Their concentrations vary depending on the degree of ventilation of the interior spaces as well as the temperature and humidity levels. For the acquisition of environmental data and physiological parameters, the following equipment were used: one router LANCOM 1780EW 4G +; two devices Libelium Plug and Sense SCP (Smart Cities Pro), SCP3 (D\#1) and SCP6 (D\#2) air quality monitoring stations; one air quality monitoring station uRADMonitor Industrial, uRAD (D\#0); one Libelium Gas Board data acquisition board with air quality monitoring sensors. The architecture of the WINS@HI project is presented in Fig. 2.

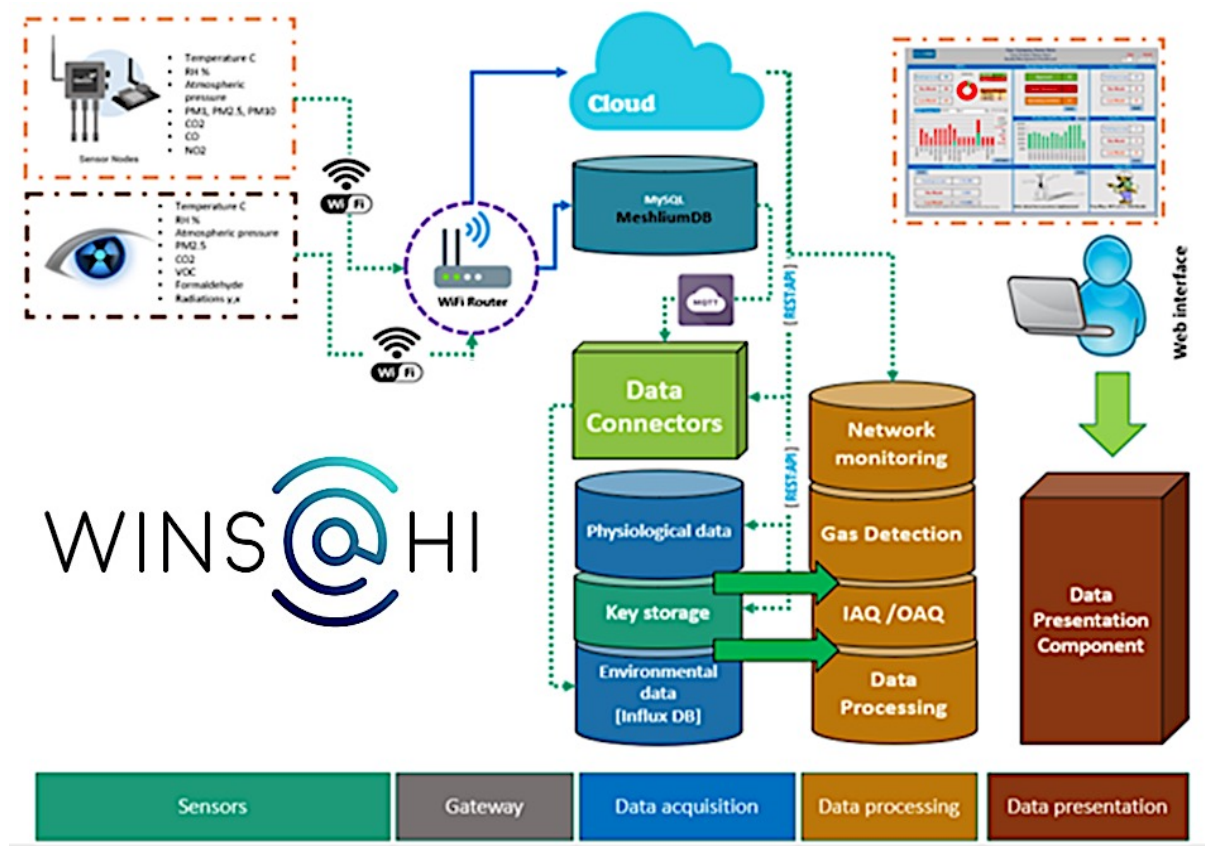

Fig. 2. Platform architecture for underground transportation pilot (Suciu et. al., 2019)

The communication center pilot (Fig. 3 ) is made up of 3 rooms ( 2 office rooms and one technical room - server room). The staff working at the location of the communications center vary between 3 to 5 people. The technical room is mostly closed, the access is restricted, and the door is rarely open for equipment maintenance. In the next figures are presented the pilot location and the installed equipment. 


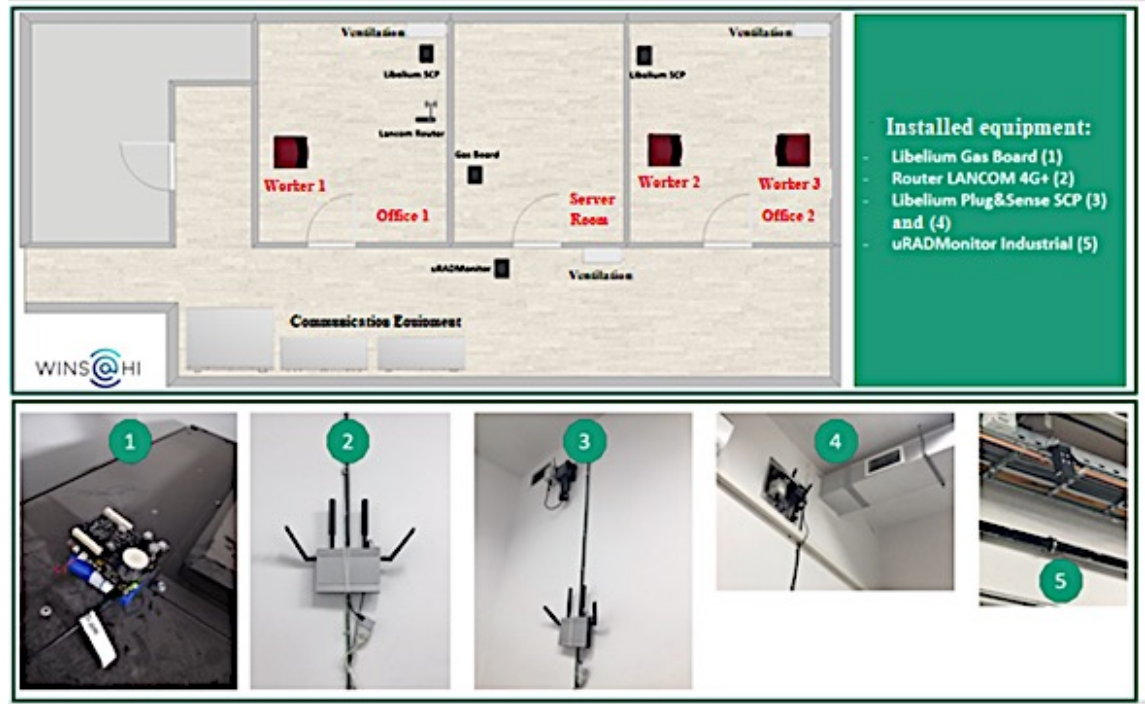

Fig. 3. Pilot Location and installed equipment (Suciu et. al., 2019)

This paper demonstrates a method that uses WINS@HI solutions for assessment and management of chronic risk that is represented by ambient air pollution and prolonged sitting. The main result of this research is represented by a data driven decision system for improving the health and safety management in underground transportation environments. This system will allow the metro management to improve the health of employers by using air purifiers that will turn on when the system will forecast high pollution episodes.

\section{EXPERIMENTS}

For the assessment of the $\mathrm{PM}_{10}$ and $\mathrm{PM}_{2.5}$ concentration, were performed measurement during the period 1 May - 30 June 2019. The data set represents 200 values of hourly concentrations for each of the $\mathrm{PM}_{10}$ and $\mathrm{PM}_{2.5}$ (Fig. 4) and are measured at the three important points of the location (central corridor and outside air intake points).

The data set was used to test the previous developed models (Suciu et al., 2019) estimate the values of the pollutant concentrations in the common spaces (the central corridor) based on the values of the concentrations measured at the outside air inlets.

The data set was used to test on a bigger dataset the previous developed models (Suciu et al., 2019) that estimate the values of the pollutant concentrations in the common spaces (the central corridor) based on the values of the concentrations measured at the outside air inlets. 


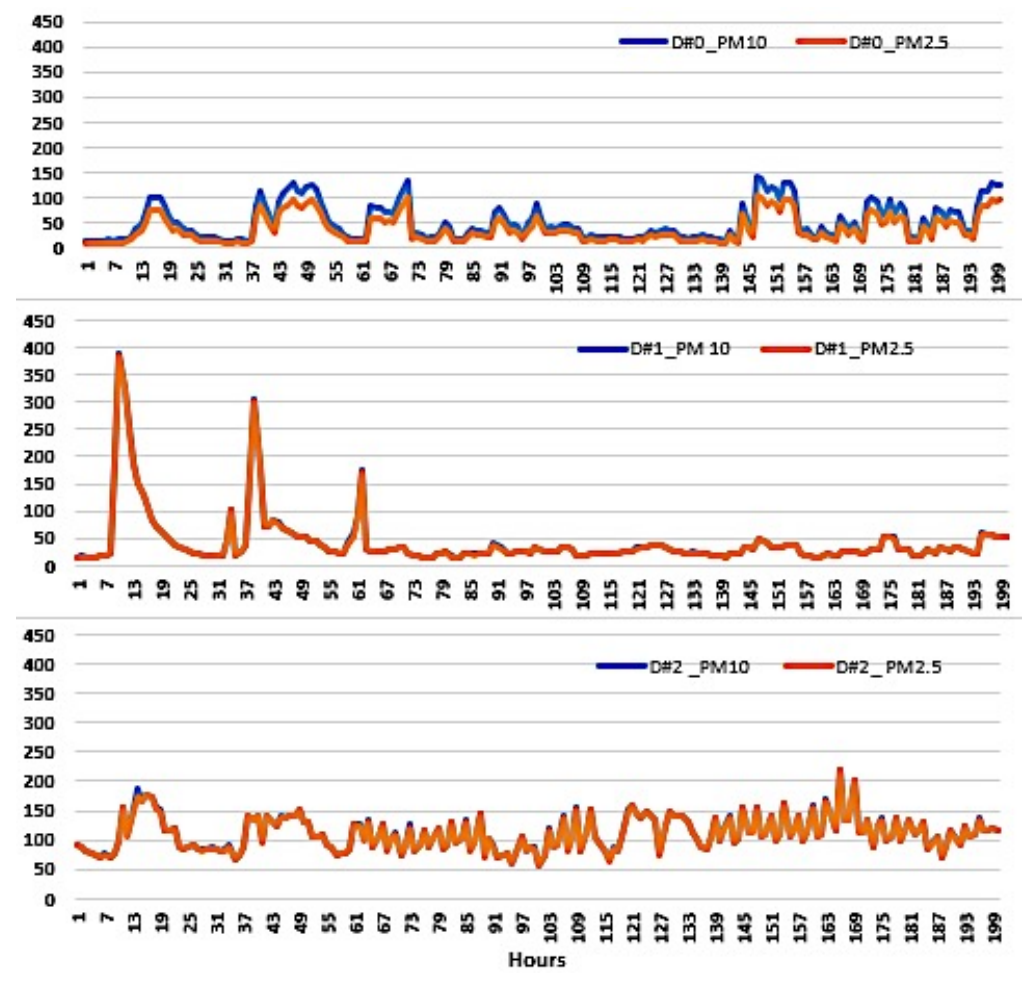

Fig. 4. $P M_{2.5}$ and $P M_{10}$ variation during the monitoring period

The model for estimating $\mathrm{PM}_{10}$ and $\mathrm{PM}_{2.5}$ concentrations ( $\mathrm{E}_{\mathrm{PM} 10}$ - Equation 1, $\mathrm{E}_{\mathrm{PM} 2.5}$ - Equation 2) performed in the previous stage of the project is presented below:

$$
\begin{aligned}
& y=1.270 * x_{1}+0.347 * x_{2}-18.610 \\
& y=0.975 * x_{1}+0.305 * x_{2}-18.013
\end{aligned}
$$

where:

$\mathbf{y}-\mathrm{PM}_{10}$ or $\mathrm{PM}_{2.5}$ concentration measured in the central corridor, $\mu \mathrm{g} / \mathrm{Nm}^{3}$

$\mathbf{x}_{1}-\mathrm{PM}_{10}$ or $\mathrm{PM}_{2.5}$ concentration measured near the admission point in room 1 (SCP3), $\mu \mathrm{g} / \mathrm{Nm}^{3}$ $\mathbf{x}_{2}-\mathrm{PM}_{10}$ or $\mathrm{PM}_{2.5}$ concentration measured near the admission point in room 3 (SCP4), $\mu \mathrm{g} / \mathrm{Nm}^{3}$

The statistical analysis (Table 1) of the data set used to validate the $\mathrm{E}_{\mathrm{PM} 10}$ and also $E_{\mathrm{PM} 2.5}$ model indicates the existence of outlier values (especially in room 1) and a higher average concentration value in room 3 (which may have as source the activities carried inside).

The model was tested on a subset of data for which the absolute percentage of deviation between the measured PMs concentration value and the estimated one in the pilot's central corridor is less than $100 \%$. Fig. 5 shows the graphical representation of the initial data set and the extracted subset. 
Table 1. The values of the statistical parameters of the data sets used to validate the $E_{P M 10}$ and $E_{P M 2.5}$ models

\begin{tabular}{|c|c|c|c|c|c|c|}
\hline \multirow{3}{*}{$\begin{array}{l}\text { Statistical } \\
\text { parameter }\end{array}$} & \multicolumn{3}{|c|}{ Measured $\mathrm{PM}_{10}$ concentrations, $\mu \mathrm{g} / \mathrm{Nm}^{3}$} & \multicolumn{3}{|c|}{ Measured $\mathrm{PM}_{2.5}$ concentrations, $\mu \mathrm{g} / \mathrm{Nm}^{3}$} \\
\hline & $\begin{array}{c}\text { Central } \\
\text { corridor }\end{array}$ & Room 1 & Room 3 & $\begin{array}{c}\text { Central } \\
\text { corridor }\end{array}$ & Room 1 & Room 3 \\
\hline & $\mathrm{D} \# 0$ & D\#1 & $\mathrm{D} \# 2$ & $\mathrm{D} \# 0$ & D\#1 & D\#2 \\
\hline $\begin{array}{l}\text { Average } \\
\text { value }\end{array}$ & 49.78 & 42.24 & 111.67 & 36.56 & 41.86 & 110.8 \\
\hline $\begin{array}{l}\text { Standard } \\
\text { error }\end{array}$ & 2.51 & 3.55 & 2.03 & 1.89 & 3.53 & 2 \\
\hline $\begin{array}{l}\text { Standard } \\
\text { deviation }\end{array}$ & 35.56 & 50.23 & 28.67 & 26.48 & 49.91 & 28.33 \\
\hline Variance & 1264.47 & 2523.13 & 821.78 & 714.85 & 2490.87 & 802.55 \\
\hline $\begin{array}{l}\text { Minimum } \\
\text { value }\end{array}$ & 11.79 & 13.83 & 56.05 & 8 & 13.5 & 55.93 \\
\hline $\begin{array}{l}\text { Maximum } \\
\text { value }\end{array}$ & 140.16 & 387.09 & 220.54 & 104.52 & 384.99 & 218.45 \\
\hline $\begin{array}{l}\text { Level of } \\
\text { confidence } \\
\text { for average } \\
\text { value }(95 \%)\end{array}$ & 4.96 & 7 & 4 & 3.73 & 6.96 & 3.95 \\
\hline
\end{tabular}

The analysis of the statistical parameters (Table 2) of the data subset indicates an improvement of the results of both the $\mathrm{E}_{\mathrm{PM} 10}$ and $\mathrm{E}_{\mathrm{PM} 2.5}$ models. Thus, the difference between the average value of the measured data and the average value of the estimated data is below $1 \%$ for $\mathrm{PM}_{10}$ and below $3 \%$ for $\mathrm{PM}_{2.5}$, and the standard deviations have comparable values.
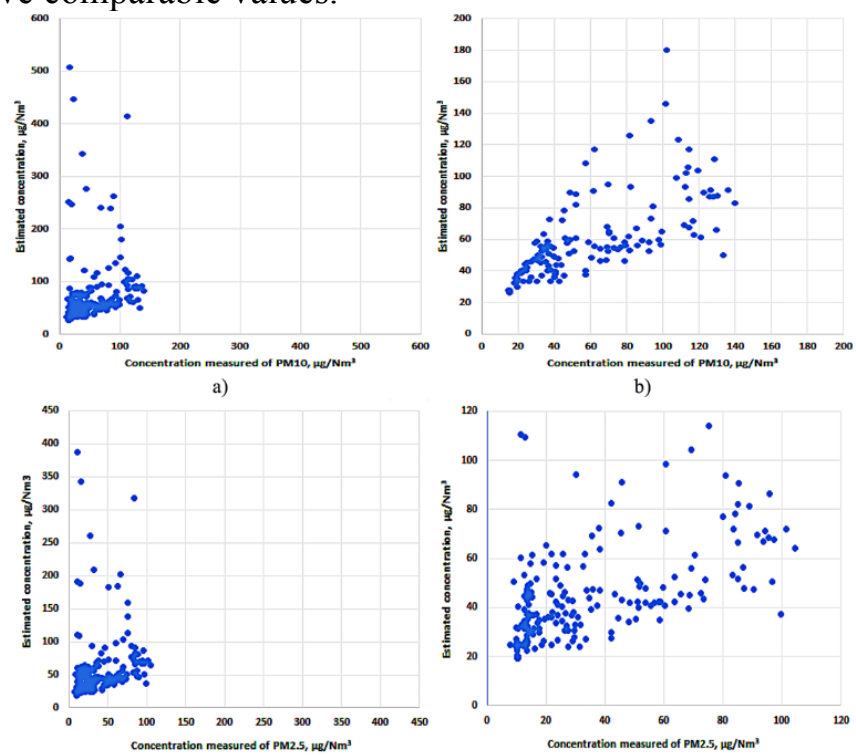

c)

d)

Fig. 5. The measured and estimated $P M_{10}$ and $P M_{2.5}$ concentration values for the initial data set (a) \& (c) and the extracted subset (b) \& (d) 
Table 2. Statistical parameter values for the subset of data used to validate $E_{P M 10}$ and $E_{P M 2.5} m o d e l s$

\begin{tabular}{|c|c|c|c|c|c|c|}
\hline \multirow[b]{2}{*}{$\begin{array}{l}\text { Statistical } \\
\text { parameter }\end{array}$} & \multicolumn{3}{|c|}{$\mathbf{E}_{\text {PM10 }}$ model } & \multicolumn{3}{|c|}{ E $_{\text {PM2.5 }}$ model } \\
\hline & $\begin{array}{c}\text { Measured } \\
\text { concentratio } \\
\mathbf{n}, \mu \mathrm{g} / \mathrm{Nm}^{3}\end{array}$ & $\begin{array}{c}\begin{array}{c}\text { Estimated } \\
\text { concentration, } \\
\mu \mathrm{g} / \mathrm{Nm}^{3}\end{array} \\
\end{array}$ & $\begin{array}{c}\text { Absolute } \\
\text { error, } \mu \mathrm{g} / \mathrm{Nm}^{3}\end{array}$ & $\begin{array}{c}\text { Measured } \\
\text { concentration, } \\
\mu \mathrm{g} / \mathrm{Nm}^{3}\end{array}$ & $\begin{array}{c}\text { Estimated } \\
\text { concentration, } \\
\mu \mathrm{g} / \mathrm{Nm}^{3}\end{array}$ & $\begin{array}{c}\text { Absolute } \\
\text { error, } \mu \mathrm{g} / \mathrm{Nm}^{3}\end{array}$ \\
\hline Average value & 61.9 & 61.23 & 21.59 & 46.53 & 44.85 & 14.86 \\
\hline Standard error & 3.08 & 2.31 & 1.38 & 2.27 & 1.49 & 0.92 \\
\hline Median value & 51.7 & 55.2 & 17.69 & 42.28 & 42.03 & 12.77 \\
\hline $\begin{array}{l}\text { Standard } \\
\text { deviation }\end{array}$ & 35.49 & 26.64 & 15.89 & 26.32 & 17.22 & 10.63 \\
\hline Variance & 1259.88 & 709.94 & 252.43 & 692.83 & 296.55 & 112.93 \\
\hline Minimum value & 14.79 & 26.45 & 0.11 & 10.34 & 19.23 & 0.30 \\
\hline Maximum value & 140.16 & 179.99 & 83.88 & 104.52 & 93.79 & 62.55 \\
\hline $\begin{array}{|lr|}\text { Level } & \text { of } \\
\text { confidence } & \text { for } \\
\text { average } & \text { value } \\
(95 \%) & \\
\end{array}$ & 6.09 & 4.57 & 2.73 & 4.5 & 2.94 & 1.82 \\
\hline
\end{tabular}

The analysis of the variation of the errors (deviations) of the estimated data compared to the measured ones (Fig. 6) indicates that the model tends to slightly overestimate the values of $\mathrm{PM}_{10}$ concentrations. The value of the correlation coefficient between the measured and the estimated values is 0.659 for $\mathrm{PM}_{10}$ and 0.723 for $\mathrm{PM}_{2.5}$.

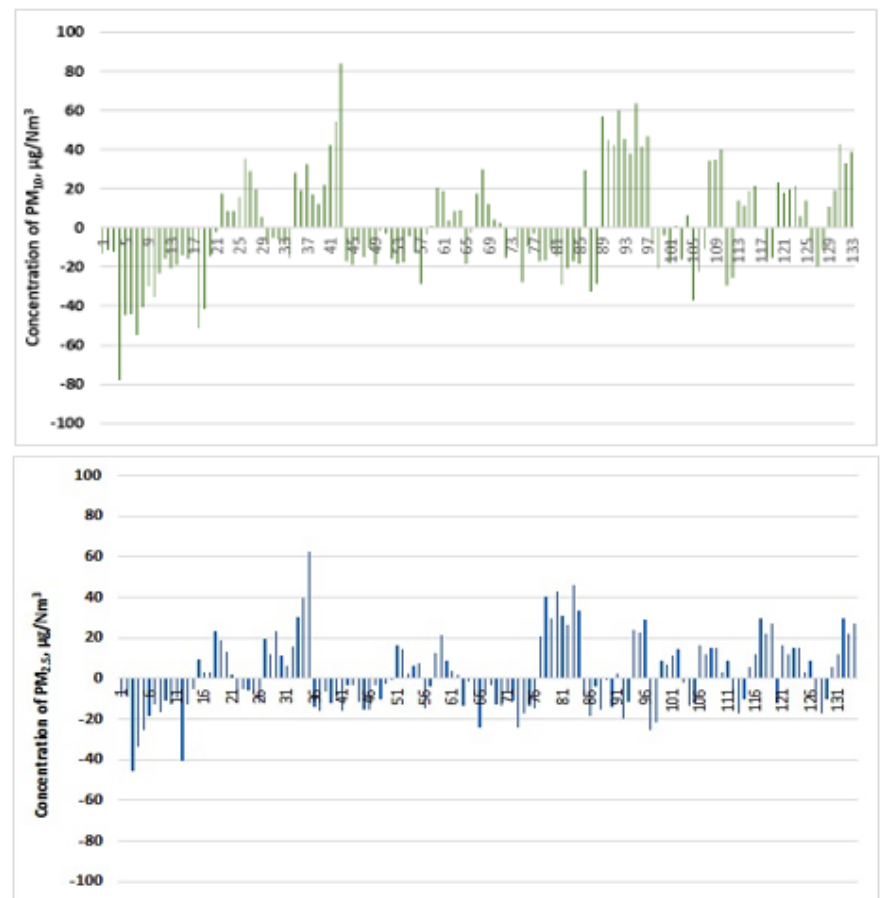

Fig. 6. Variation of the differences between the measured and estimated PM 10 (up) and $\mathrm{PM}_{2.5}$ (down) concentrations values 


\section{CONCLUSION}

The $\mathrm{PM}_{10}$ and $\mathrm{PM}_{2.5}$ hourly concentration values for all measurement points show a similar pattern explained by the higher percentage of $\mathrm{PM}_{2.5}$ from $\mathrm{PM}_{10}(72 \%$ for $\mathrm{D \# 0}$ and $99 \%$ for D\#1 and D\#2).

Considering also that $\mathrm{PM}_{10}$ and $\mathrm{PM}_{2.5}$ concentrations measured in the points $\mathrm{D \# 1}$ and $\mathrm{D} \# 2$ are situated next to the air admissions point and the proximity to the road traffic there is a strong indication that the main source for these pollutants in the pilot location are urban road traffic.

The model for estimation of the $\mathrm{PM}_{10}$ and $\mathrm{PM}_{2.5}$ hourly concentrations on the central hall point of the case study based on concentrations measured near to the outside air admissions point predict very well the concentrations.

Considering the measured pollution level, several solutions for reducing the indoor air pollution will be studied. One of them could be installing air purifiers that integrate various air quality sensors and to improve the working environment.

\section{ACKNOWLEDGMENTS}

The work presented in this paper has been funded by UEFISCDI Romania through WINS@HI project (PN-III-P3-3.5-EUK-2017-02-0038), Tel-MONAER project (subsidiary contract no. 1223/22.01.2018, from NETIO Project ID: P 40270, MySMIS CODE: 105976), ESTABLISH project (PN-III-P3-3.5-EUK-2016-0011), SARWS, POLDER and SWAM projects.

\section{REFFERENCES}

1. Aarnio P., Yli-Tuomi T., Kousa A., Mäkelä T., Hirsikko A., Hämeri K., Räisänen M., Hillamo R., Koskentalo T., Jantunen M. (2005). The concentrations and composition of and exposure to fine particles $\left(\mathrm{PM}_{2.5}\right)$ in the Helsinki subway system. Atmospheric Environment, 39(28):5059-66. DOI: https://doi.org/10.1016/j.atmosenv.2005.05.012.

2. Barmparesos N., Assimakopoulos V., Assimakopoulos M., Tsairidi E. (2016), Particulate matter levels and comfort conditions in the trains and platforms of the Athens underground metro, Environmental Science, vol. 3, pp. 199-219. DOI: https://doi.org/10.3934/environsci.2016.2.199.

3. Carteni A., Cascetta F. (2018), Particulate matter concentrations in a high-quality rubber-tyred metro system: the case study of Turin in Italy, International Journal of Environmental Science and Technology, vol. 15, pp. 1921-1930. DOI: https://doi.org/10.1007/s13762-017-1566-x.

4. Carteni A., Campana S. (2014), Particulate Matter concentrations in a new section of metro line: a case study in Italy, WIT Transactions on the Built Environment, vol. 135, pp. 523-534. DOI: https://doi.org/10.2495/CR140431.

5. Pan S, Du S., Wang X., Zhang X., Xia L., Jiaping L., Pei F., Wei Y. (2018), Analysis and interpretation of the particulate matter $\left(\mathrm{PM}_{10}\right.$ and $\left.\mathrm{PM}_{2.5}\right)$ concentrations at the subway stations in Beijing, China. DOI: https://doi.org/10.1016/j.scs.2018.11.020. 
6. Perrino C., Marcovecchio F., Tofful L., Canepari S. (2015), Particulate matter concentration and chemical composition in the metro system of Rome, Italy, Environmental Science and Pollution Research, 22:9204. DOI: https://doi.org/10.1007/s11356-014-4019-9

7. Prüss-Üstün A. Corvalan C. (2016), Preventing disease through healthy environments: a global assessment of the burden of disease from environmental risks, World Health Organization, ISBN 9789241565196.

8. Suciu G., Balanescu M., Nadrag C., Birdici A., Balaceanu C., Dobrea M., Pasat A. (2019), Wearable IoT Network Solution for Work Safety in Hazardous Industrial Environments - WINS@HI, PN-III-P3-3.5-EUK-2017-02-0038, National Report.

9. Suciu G., Balanescu M., Nadrag C., Birdici A., Balaceanu C., Dobrea M., Pasat A., Ciobanu R. (2019), IoT System for Air Pollutants Assessment in Underground Infrastructures, Proceedings of the 6th Conference on the Engineering of Computer Based Systems (pp. 1-7. DOI: https://doi.org/10.1145/3352700.3352710.

10. World Health Organization (2019), Air pollution, Overview. URL: https://www.who.int/health-topics/air-pollution\#tab=tab 1, Accessed on 20.12.2019. 